\title{
Physical factors in benthic ecology: effects of changing sand particle size on beach fauna
}

\author{
Anton McLachlan* \\ Zoology Department, University of Port Elizabeth, PO Box 1600, Port Elizabeth 6000, South Africa
}

\begin{abstract}
This paper reports on the disposal of diamond mine tailings on a Namibian sandy beach. Coarse sand in the tailings greatly increases the grain size of the affected parts of the beach and thereby provides the opportunity to assess the effects of changing sand grain size on a beach when other physical variables are kept constant. Elizabeth Bay (Namibia) is $4 \mathrm{~km}$ long and was originally corrposed of fine sand which, exposed to moderate to heavy wave action, produced a log spiral bay with a dissipative beach. Tailings disposal in the centre of the bay has increased mean sand particle size from original values of 110 to $160 \mu \mathrm{m}$ to present values of 500 to $800 \mu \mathrm{m}$ with a concomitant conversion of beach morphodynamic state from dissipative to intermediate. Surveys of the 2 ends of the bay. which are relatively unaffected by disposal, and of an undisturbed similar bay nearby revealed intertidal benthic macrofauna communities with 15 to 20 species occurring in high abundance $(24120$ to $129276 \mathrm{~m}^{-1}$ ). In 3 transects in the affected area, species richness was 8 to 12 per transect and abundance was 640 to $4710 \mathrm{~m}^{-1}$ Beds of the large sand mussel Donax serra have disappeared from the affected sector of the bay and peracarids typical of finer sands have been replaced by a more robust species. Regression analysis revealed significant correlations between community parameters (species richness and abundance) and both beach slope and particle size; ANOVA confirmed the significantly lower abundances of fauna in the affected areas. Smothering effects appeared to be localised and limited. This study has supported the hypothesis that an increase in sand particle size (on a beach where tide range and wave energy have remained constant) results in a change in beach state and a decrease in species richness and abundance.
\end{abstract}

KEY WORDS: Sandy beach · Benthic macrofauna - Environmental gradients Grain size

\section{INTRODUCTION}

Physical factors such as sediment texture have long been acknowledged to be important in benthic ecology (Johnson 1971, Gray 1974). However, it has been more popular to investigate biological factors structuring benthic communities, and considerably more attention is paid to competition, predation and recruitment (Olafsson et al. 1994) than to physical properties of the sediment or water column. In some situations, however, physical factors are of such overriding importance that they are not easily deposed from centre stage. Exposed sandy beaches are physically dynamic benthic environments which can be defined by 3 vari-

-E-mail: agr3629@squ.edu ables: wave energy, tide range and sand particle size. These 3 factors interact to produce 4 general beach morphodynamic types: microtidal reflective, micro/ mesotidal intermediate, micro/mesotidal dissipative and macrotidal ultradissipative (Short \& Wright 1983 , Masselink \& Short 1993). Thus, as tide range or wave energy increases or sand particle size decreases, beaches become wider, flatter and more dissipative.

Faunal communities increase linearly in species richness and exponentially in abundance over this range of beach types (McLachlan 1990, McLachlan et al. 1993). On dissipative beaches a wide range of species occurs, but, as more reflective conditions are approached, species are excluded, leaving, in the most reflective extremes, intertidal zones devoid of intertidal macrofauna and only supralittoral forms present (Jaramillo et al. 1993). Intertidal animals on exposed sandy beaches 
experience environmental change across a gradient of beach types as changes in 2 features: swash climate (i.e. water movement) on the beach face (McArdle \& McLachlan 1992) and sand particle size. The elimination of species along the gradient of beach morphodynamic types is therefore largely due to exclusion by increasingly harsh swash climate and/or coarser sand leading towards the reflective extreme (Nel 1995, McLachlan et al. in press).

Since beach communities are physically controlled, community structure must result primarily from the responses of individual species to changes in swash climate or particle size over a range of beach types. As manipulative experimentation is not possible on exposed beaches, elucidation of the relative roles of swash and sand in controlling the fauna is problematic and needs to be approached indirectly. However, swash and particle size effects may be separated by taking a natural beach and maintaining either wave energy or sand particle size as a constant and varying the other. Such experiments require major engineering feats and are beyond the financial abilities of even the most well-funded ecologists. However, coastal engineering activities conducted for other purposes sometimes provide unique opportunities to examine the response of beach fauna to major physical changes in their environments. In most cases where fill is added to a beach, the material is similar to or finer than the original beach material since it is derived from lower energy environments (Naqvi \& Pullen 1982, Gorzelany \& Nelson 1987). Addition of coarser material would be expected to have different effects; it would be expected to exclude species (J. Dugan, A. McLachlan, E. Jaramillo unpubl.) and thus change community composition through direct particle size effects.

This paper aims to test the hypothesis that increasing the sand particle size on a beach will change the morphodynamic state towards the reflective condition and cause a decrease in species richness and abundance of the benthic macrofauna community. It reports on a case in Namibia where disposal of tailings from coastal diamond mining has resulted in great changes in the sand grain sizes on a natural beach which previously supported a rich intertidal benthic community

\section{MATERIALS AND METHODS}

Study area and sampling sites. This study was undertaken in Diamond Area 1, which covers the southern sector of the Namibian coast from the Orange River to Luderitz. Protected by tight security and previously closed to scientists, this area has recently been opened to scientific study for impact assessment and environmental management purposes. The mining company, CDM, requested examination of the effects of mine tailings disposal on Elizabeth Bay beach (Fig. 1), but only after disposal had been going on for 2 yr. This unfortunately excluded the taking of 'before' and 'after' samples. To rectify this flaw, another similar but undisturbed beach, Grossebucht, was examined.

Elizabeth Bay is a south-facing embayment located on the Namibian coast $30 \mathrm{~km}$ south of Luderitz (Fig. 1). The bay is flanked by the rocky Elizabeth Point to the west and rocky shores backed by dunes to the east and

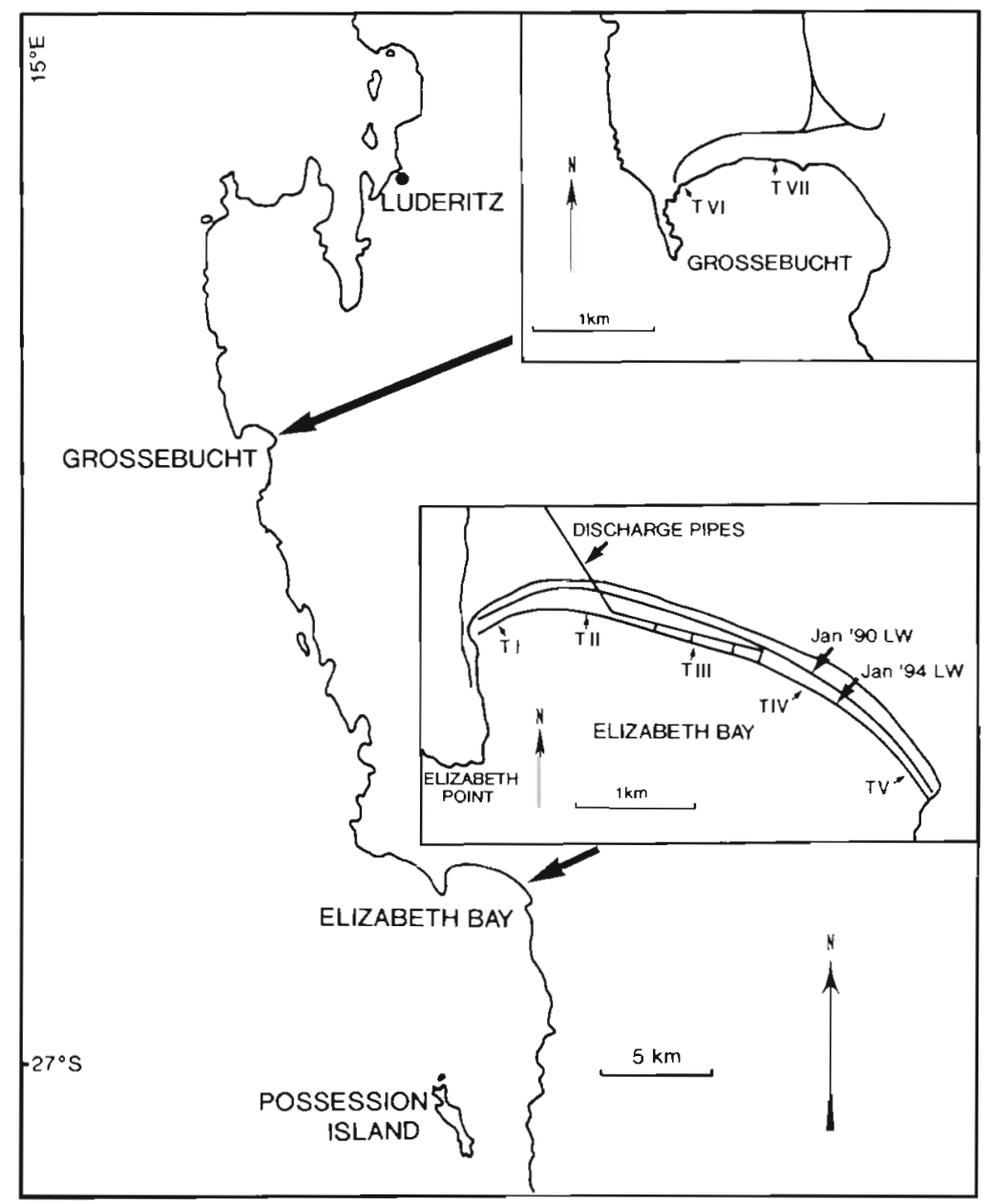

Fig. 1. Namibian coast south of Luderitz, showing Elizabeth Bay and Grossebucht (Africa). Inset: sampling sites in Elizabeth Bay and Grossebucht. ShoreIne positions in Elizabeth Bay are shown for 1990 and 1994 
receives some limited protection from southerly swell from Possession Island located $9 \mathrm{~km}$ to the south. The beach, $4 \mathrm{~km}$ long, forms a weak log spiral with the western end sheltered behind Elizabeth Point, with exposure increasing eastward. It is backed by a narrow field of hummock dunes colonised primarily by the salt bush Salsola. Behind the dunes is a broad deflation plain of low-lying damp sediment. Tailings from Elizabeth Bay Mine are discharged alternately through 4 outlets located near the centre of the bay over a distance of about $600 \mathrm{~m}$.

The beach ranges from low energy dissipative in the west to high energy dissipative in the east, but with medium to high energy intermediate states in the centre where it has been modified by tailings disposal. Only in the sheltered western sector of the beach does a significant quantity of stranded material, mainly kelp, accumulate. Beach profiles have been monitored since discharge started in 1991 (CSIR 1993a). Central sections of the beach have been prograding as a result of accumulation of discharged sediments (Fig 1), and beach profiles have steepened from the first surveys in 1990 to the present time.

Grossebucht Bay, $10 \mathrm{~km}$ from Luderitz (Fig. 1), also faces south but is more protected behind a rocky point to the west, resulting in lower energy wave action than that experienced in Elizabeth Bay. The beach is $1.5 \mathrm{~km}$ long, with a small rocky outcrop towards the east, and ranges from low energy dissipative to medium energy dissipative with a flat gradient throughout. It corresponds in exposure to the western sector of Elizabeth Bay. It is also backed by a narrow band of dune hummocks giving way to a deflation plain. A considerable amount of stranded material, mainly kelp, accumulates along the drift line at the dune base.

Swell mainly approaches this coast from the west to southwest and predominant winds are southerly through most of the year. There are virtually no calms, and secondary winds, northwesterlies and warm, dry easterlies blow mainly in autumn and winter. This is an upwelling coast, and inshore water temperature mostly ranges from 10 to $15^{\circ} \mathrm{C}$. Tides are semidiurnal subequal with an extreme range of $2 \mathrm{~m}$.

The fine tailings disposed of on Elizabeth Bay beach are suspended in seawater which discharges at rates of 30000 to $180000 \mathrm{~m}^{3} \mathrm{mo}^{-1}$ (CSIR 1993b). This carries a variable load of suspended sediment with median grain sizes of 150 to $900 \mu \mathrm{m}$ and $90 \%$ of grains are usually in the size range of 125 to $1400 \mu \mathrm{m}$. The coarser fractions tend to remain on the beach, whereas the finer components are dispersed offshore in turbid plumes which generally disperse before exiting the bay (CSIR 1993b). There is no contamination of the discharged sands and, since they are aeolian sands but of marine origin, they are well rounded, as are the beach sands.
The CSIR Report (1993a) listed breaker zone widths at the 4 disposal pipe sites in the centre of Elizabeth Bay as ranging from 0 to $500 \mathrm{~m}$ in the west and 50 to $600 \mathrm{~m}$ in the east, and regular accretion was recorded at all 4 sites, totalling $200 \mathrm{~m}$ in the centre of the disposal area over 2 yr. CSIR (1993a) profiles in the centre of the beach, where disposal is concentrated, showed beach face slopes of about $1 / 70$ in 1990 before tailings disposal increasing to 1/15 in 1992. At the western end of the beach, $1 \mathrm{~km}$ from the nearest disposal pipe (but subject to some limited local disposal), accretion has been about $50 \mathrm{~m}$ and slopes have steepened from 1/70 to $1 / 55$. At the exposed eastern end, $1.5 \mathrm{~km}$ from the nearest pipe, accretion was $<50 \mathrm{~m}$ and beach face slope remained fairly constant around $1 / 70$.

Five transects (I-V) were located in Elizabeth Bay (Fig. 1): I in the sheltered western sector, in a beach state judged to be low energy dissipative; II in a medium energy intermediate state; the central transect III in a medium to high energy intermediate beach state between discharge pipes; IV in a high energy intermediate beach state; and $V$ in high energy dissipative conditions. Transects I and $V$ were in parts of the beach hardly affected by tailings disposal, whereas Transect III was strongly affected and Transects II and IV were moderately affected. Two transects (VI-VII) were located in Grossebucht Bay. At transect VI, the beach was in a low energy dissipative state and at Transect VII, it was in a low to medium energy dissipative state.

Sampling and analytical procedures. Transect surveys were carried out during the calm period, in June 1994, using standard methods. For each transect, a line perpendicular to the shore was surveyed from above the drift line (previous high tide swash line) to the lowest point of the swash during low tide using a tape measure and surveyor's level. Along this line, 10 stations were positioned at equal horizontal intervals, with the second station downshore being on the driftline. In addition to these 10 stations, a further station was sampled in the surf zone at a depth $1 \mathrm{~m}$ below the elevation of Stn 10. At each station, including the subtidal, 3 replicate quadrats of $0.1 \mathrm{~m}^{2}$ were excavated to $25 \mathrm{~cm}$ and the sand washed through bags of $1 \mathrm{~mm}$ mesh using the same procedure. All fauna retained in the bags were preserved in 5 to $10 \%$ formalin.

Additional information gathered at each transect included the nature of the drift line, the position of the water table, the state and extent of the surf zone (after Short \& Wright 1983) and the collection of sand samples (top $5 \mathrm{~cm}$ ) at Stns 1, 5 and 10 (i.e. above the drift line, mid tide level and low tide level) and at $-1 \mathrm{~m}$ (i.e. in the surf zone). Sediment samples of approximately $10 \mathrm{~g}$ were analyzed by settling tube. From this a computer program (J. Reddering pers. comm.) generated 
distribution statistics, settling velocities and graphical and moment parameters. Only distribution statistics and graphical statistics were used further

In the laboratory, all specimens were identified and enumerated, and biomass (shell-free) was determined by drying at $60^{\circ} \mathrm{C}$ for $48 \mathrm{hr}$. Kite diagrams were constructed and abundance and biomass for each species were calculated for $1 \mathrm{~m}$ wide transects of beach by linear interpolation. This was done for the intertidal alone (Stns 1 to 10) and for the intertidal plus shallow subtidal (i.e. down to $-1 \mathrm{~m}$ ).

Differences in abundance between transects based on individual quadrats (33) per transect were tested for significance using 1-way ANOVA after testing of these data for normality and transforming using ln. Intratransect variability was assessed using 1-way ANOVAs to test for differences between lines (3) and levels (10) for each transect. Relationships between species richness and abundance of macrofauna and physical variables were analysed by least squares regression analysis. Species/area plots for each transect were performed using the program of Hartnoll (1983), and the species and environmental (sand particle size, beach face slope and wave height) data were subject to multivariate analysis in the form of Detrended Canonical Correspondence Analysis (DCCA; Ter Braak 1987) with site scores obtained from species scores and as linear combinations of environmental variables.

\section{RESULTS}

\section{Sediment analysis}

The results of settling tube analysis of sand samples are summarised in Table 1 Transects VI and VII at Grossebucht, which served as a reference, were both characterised by very fine sand with mean particle sizes in the range of 84 to $100 \mu \mathrm{m}$ at all tide levels. The less sheltered Transect VII had slightly coarser sand than the sheltered Transect VI. Particles above $125 \mu \mathrm{m}$ made up $<10 \%$ and mud (subsieves $<60 \mu \mathrm{m}$ ) $<2 \%$ Furthermore, the low sorting coefficients (Table 1) indicate that these sands are exceptionally well sorted

Samples taken on the backshore in the centre of Elizabeth Bay (Transect III) at positions corresponding to the 1990 high, mid and low tide levels all contained fine to very fine sand in the particle size range 114 to $135 \mu \mathrm{m}$. This was well sorted, with $<1 \%$ medium sand above $250 \mu \mathrm{m}$ particle diameter and $<3 \%$ mud below $60 \mu \mathrm{m}$. In contrast, a layer of tailings sand above the fine sand of the original low tide level had a mean particle size of $331 \mu \mathrm{m}$, moderate sorting and $16.2 \%$ of sand $>500 \mu \mathrm{m}$. This clearly indicates that the natural
Table 1 Graphical statistics of sand samples taken from the top $5 \mathrm{~cm}$ at Elizabeth and Grossebuch.t Bays (Namibia) along 7 transects (I-VII) and near an effluent pipe in 1994 and at 30 and $150 \mathrm{~cm}$ depth on the shoreline at Elizabeth Bay in 1990. Md: median; Mn: mean; Sort: sorting; Skew: skewness. H, M, and $\mathrm{L}$ : high, mid and low tide levels, respectively; $-1 \mathrm{~m}$ : $1 \mathrm{~m}$ into the surf zone

\begin{tabular}{lrrrrr|}
\hline Transect \& level & Md $\phi$ & Mn $\phi$ & Mn $\mu m$ & Sort $\phi$ & Skew $\phi$ \\
\hline 1994 & & & & & \\
I H & 2.95 & 2.87 & 137 & 0.20 & -0.43 \\
I M & 2.65 & 2.62 & 163 & 0.28 & -0.12 \\
I L & 2.79 & 2.83 & 141 & 0.20 & 0.18 \\
I -1 m & 2.96 & 2.89 & 135 & 0.26 & -0.28 \\
II H & 0.78 & 0.92 & 530 & 0.57 & 0.24 \\
II M & 1.61 & 1.55 & 341 & 0.38 & -0.14 \\
II L & 1.03 & 1.09 & 468 & 0.62 & 0.11 \\
II - I m & -0.10 & -0.02 & 1014 & 0.26 & 0.31 \\
III H & -0.11 & 0.04 & 975 & 0.29 & 0.48 \\
III M & 0.60 & 0.67 & 629 & 0.45 & 0.16 \\
III L & 0.06 & 0.15 & 902 & 0.37 & 0.23 \\
III - I m & 0.20 & 0.70 & 614 & 0.96 & 0.52 \\
IV H & 1.78 & 1.75 & 297 & 0.38 & -0.06 \\
IV M & 0.98 & 1.07 & 475 & 0.32 & 0.30 \\
IVL & 0.05 & 0.1 .3 & 914 & 0.26 & 0.30 \\
IV -1 m & 1.13 & 1.19 & 438 & 0.50 & 0.13 \\
V H & 2.22 & 2.22 & 215 & 0.22 & -0.01 \\
V M & 2.44 & 2.41 & 189 & 0.35 & -0.11 \\
V L & 2.22 & 2.24 & 21.2 & 0.34 & 0.04 \\
V -1 m & 2.50 & 2.49 & 178 & 0.32 & -0.03 \\
VI H & 3.46 & 3.47 & 90 & 0.11 & 0.10 \\
VI M & 3.44 & 3.46 & 91 & 0.12 & 0.17 \\
VI L & 3.41 & 3.45 & 92 & 0.14 & 0.28 \\
VI -1m & 3.45 & 3.48 & 89 & 0.14 & 0.23 \\
VII H & 3.29 & 3.34 & 99 & 0.19 & 0.26 \\
VII M & 3.35 & 3.38 & 96 & 0.16 & 0.18 \\
VII L & 3.36 & 3.42 & 94 & 0.17 & 0.21 \\
VII -1 m & 3.29 & 3.32 & 100 & 0.29 & 0.12 \\
Effluent 1 & 1.91 & 1.71 & 306 & 0.83 & -0.24 \\
Effluent 2 & 1.96 & 1.77 & 293 & 0.92 & -0.21 \\
1990 & & & & & \\
H 150 & 2.98 & 3.00 & 125 & 0.19 & 0.13 \\
H 30 & 3.08 & 3.13 & 114 & 0.21 & 0.21 \\
M 150 & 3.06 & 3.09 & 117 & 0.18 & 0.17 \\
M 30 & 3.08 & 3.13 & 114 & 0.21 & 0.25 \\
L 150 & 2.86 & 2.89 & 135 & 0.22 & 0.15 \\
L 30 & & & & & \\
& & & & & \\
\hline
\end{tabular}

beach sands of both Elizabeth Bay and Grossebucht were fine to very fine and very well sorted.

Sediment samples collected from the effluent pipe discharging onto the beach had a mean grain size of $300 \mu \mathrm{m}$. The very poorly sorted sand in the effluent included nearly $20 \%$ coarser than $500 \mu \mathrm{m}$ and $3.5 \%$ mud, with the bulk (77\%) in the size range 125 to $500 \mu \mathrm{m}$.

Samples collected along the 5 Elizabeth Bay transects varied widely. Transects I and V, located at the 2 ends of the beach and least affected by tailings disposal, recorded the finest sediment. Transect I, in shel- 
tered conditions with little accretion, had well sorted fine sands with mean particle sizes in the range 116 to $163 \mu \mathrm{m},<1 \%$ coarser than $250 \mu \mathrm{m}$ and $<3 \%$ mud. Transect $V$, with hardly any accretion, had fine sands with particle size means in the range 178 to $215 \mu \mathrm{m}$, up to $28 \%$ coarser than $250 \mu \mathrm{m}$ and about $1 \%$ mud. The other 3 transects, where the beach was more directly affected by tailings accumulation and exhibited pronounced progradation, had coarser sediments.

Transect III, in the centre of the disposal area, had mean particle sizes in the coarse sand range 614 to $975 \mu \mathrm{m}$, whereas transects II and IV had medium to coarse sands with mean particle sizes in the range 297 to $1014 \mathrm{\mu m}$. Sorting in all these samples was moderate to poor and several samples had significant proportions coarser than $1000 \mu \mathrm{m}$. Mud content was generally around $1 \%$. There were no clear trends up-or downshore and there was considerable variability among these samples, indicating alternating patches of coarser and less coarse sand.

These data document the conversion of Elizabeth Bay beach from an initial state of fine to very fine sand to the present condition where tailings disposal has caused a dramatic increase in particle sizes to medium to coarse sand throughout most of the central part of the beach. After $3 y r$, this has left only the extreme western and eastern ends (Transects I and V) in conditions which approach the original state. Clearly, a wide range of particle sizes are introduced in the tailings, but fine grains are removed by wave action and transported of fshore, leaving only the coarser fractions on the beach. Furthermore, the coarsest particles are subjected to limited transport and accumulate close to the outfalls. Since this coarse material is not readily removed, recovery is unlikely.

\section{Beach profiles}

Beach profiles and water table positions are illustrated in Figs. 2 to 4 . The 2 reference transects in
Grossebucht exhibited flat profiles and low to medium energy dissipative surf zones. As a result of the combination of very fine sands and gentle slopes, water tables were shallow and the effluent line high on the beach face. In Elizabeth Bay, the 3 central transects exhibited much steeper profiles than did the ends. This steepening is in sharp contrast to all other transects and reflects the development of an intermediate beach state as a result of the addition of coarser sediment.

\section{Macrofauna}

Faunal distribution is illustrated in Figs. 2 to 4 and abundance and biomass are summarised in Table 2. A total of 30 species was recorded, of which 4 were insects or arachnids. Forms typical of the Namibian coast (Donn \& Cockcroft 1989) dominated all tide levels. The air-breathing crustaceans Talorchestia quadrispinosa and Tylos granulatus, along with kelp flies and coleopterans, occupied the supralittoral. The isopods Excirolana natalensis, Pontogeloides latipes and Eurydice longicornis, spat of the bivalve Donax serra and polychaetes, especially Scolelepis squamata, dominated the midshore. Many species occurred on the lower shore and in the shallow surf zone, especially at the transects where the beach was dissipative: e.g. the gastropod Bullia tenuis, Donax serra adults, Urothoe sp. and other amphipods, and the mysid Gastrosaccus psammodytes.

Transect I (Fig 2; Table 2) supported 19 species: 1 insect, 16 supra- and intertidal species and 2 subtidal species. Peracarid crustaceans dominated the fauna numerically, followed by molluscs and annelids. Abundance (24 120 individuals per running metre) was high, and biomass $\left(710 \mathrm{~g} \mathrm{~m}^{-1}\right)$ was high but not exceptional. Transect II (Fig. 3; Table 2) included fewer species (12): 2 supralittoral crustaceans and 10 intertidal species, with peracarids again dominant. Whereas Transect I harboured Eurydice longicomis and Pontogeloides

Table 2. Summary of general attributes of 7 transect lines (Stns 1 to 10 for each transect) surveyed on Elizabeth Bay and Grossebucht beaches. DIS: dissipative; INT intermediate. For species number, abundance and biomass, only supra- and intertidal 'marine' species are included, i.e. insects and arachnids are omitted

\begin{tabular}{|lccccccc}
\hline & Transect: & I & II & III & IV & V & VI \\
\hline Overall beach face slope & I/51 & $1 / 23$ & $1 / 17$ & $1 / 25$ & $1 / 56$ & $1 / 58$ & $1 / 59$ \\
Overall beach state & DIS & INT & INT & VINT & DIS & DIS & DIS \\
Mean particle size $(\mu \mathrm{m})$ & 144 & 588 & 780 & 531 & 199 & 91 & 95 \\
Sorting & 0.24 & 0.46 & 0.52 & 0.36 & 0.31 & 0.13 & 0.2 \\
Breaker height $(\mathrm{m})$ & 0.4 & 0.8 & 1 & 1.4 & 1.6 & 0.4 & 0.6 \\
Number of species & 16 & 12 & 8 & 9 & 15 & 16 & 17 \\
Abundance $\left(\mathrm{m}^{-1}\right)$ & 24120 & 4710 & 640 & 1067 & 24330 & 129276 & 45701 \\
Biomass $\left(\mathrm{g} \mathrm{m}^{-1}\right)$ & 710 & 4 & 6 & 78 & 5941 & 221 & 202 \\
\hline
\end{tabular}




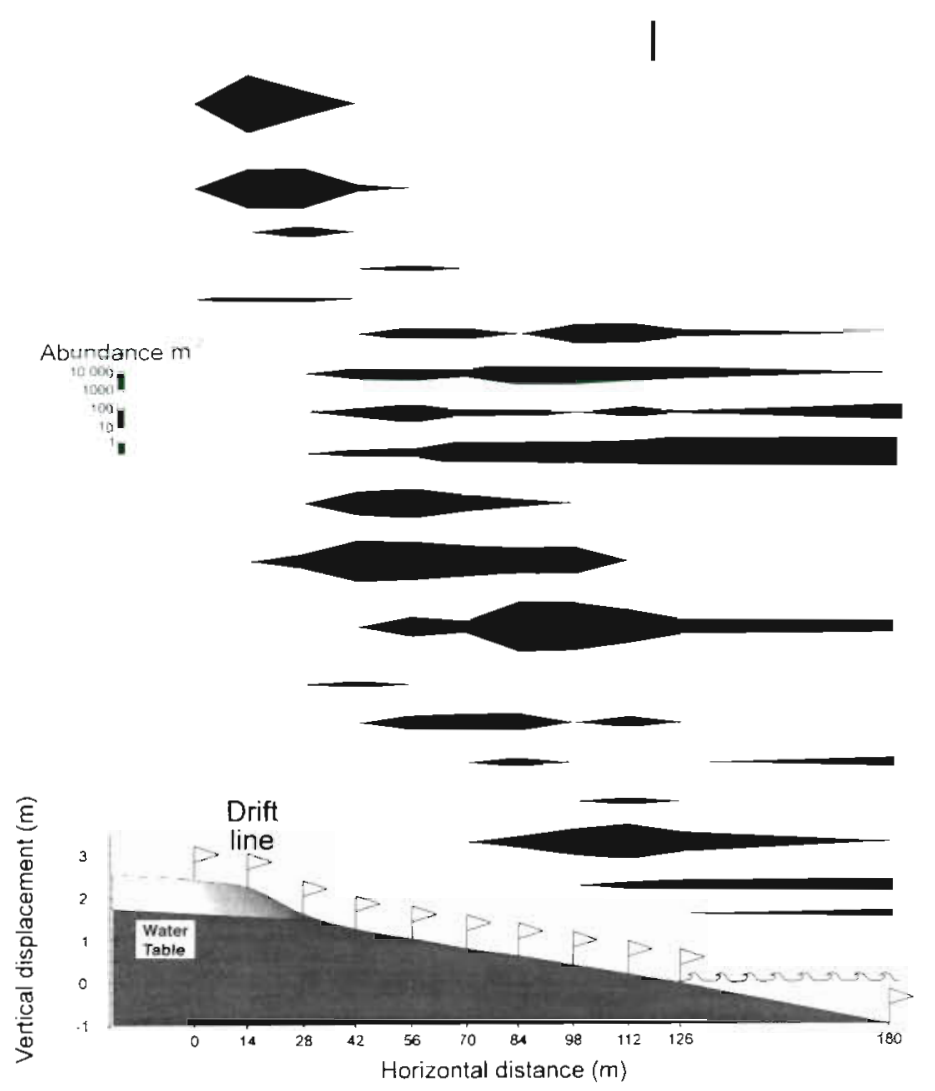

\author{
Kelp fly pupae \\ Talorchestia quadrispinosa \\ Pontogeloides latipes \\ Lumbrineris tetraura \\ Tylos granulatus \\ Scolelepis squamata \\ Cumopsis sp. \\ Donax serra \\ Urothoe sp. 1 \\ Donax serra spat \\ Eurydice longicomis
}

Gastrosaccus psammodytes

Tellina trilatera

Nephtys capensis

Paramoera capensis

Maldanidae sp.

Bullia tenuis

Sigalion capense Anthuridae sp

Fig. 2. Transect I, Elizabeth Bay Namibia. Flags indicate sampling stations with Stn 1 at the top of the shore, Stn 10 at the bottom and $-1 \mathrm{~m}$ in the sub-tidal. Kites show abundance $\mathrm{m}^{-2}$; note ln scale latipes, both typical of fine sands, Excirolana natalensis made an appearance at Transect II, presumably in response to the coarser sands encountered there. Abundance and biomass were moderate to low (4710 $\mathrm{m}^{-1}$ and $4 \mathrm{~g} \mathrm{~m}^{-1}$ ). Transect III, in the discharge area, harboured only 8 species for an abundance of $640 \mathrm{~m}^{-1}$ and a biomass of $6 \mathrm{~g} \mathrm{~m}^{-1}$ (Fig. 3i Table 2). This impoverished fauna included Tylos granulatus in the supralittoral and predominantly peracarids in the intertidal and below. Excirolana natalensis was the dominant intertidal isopod and Eurydice longicornis occurred at the $-1 \mathrm{~m}$ station. Transect IV, $1200 \mathrm{~m}$ from the centre of the disposal area, revealed 13 species, of which 4 were insects or arachnids and 9 were supra- or intertidal 'marine' species (Fig. 3i Table 2). All intertidal species were peracarids except Donax serra. Excirolana natalensis was again the dominant intertidal isopod and Eurydice longicornis occurred predominantly in the subtidal. Total abundance was $1067 \mathrm{~m}^{-1}$ and biomass was $78 \mathrm{~g} \mathrm{~m}^{-1}$ Transect $\mathrm{V}$ harboured 21 species: 5 insects, an arachnid and 15 supraand intertidal marine species (Fig. 3; Table 2). Talorchestia quadrispinosa, Tylos granulatus and insects occurred in the supralittoral. The intertidal was dominated by peracarids, although molluscs and polychaetes were more abundant than at Transects II-IV Donax serra had a sizeable intertidal spat cohort and large subtidal adult stocks, of which only the fringe was sampled. Abundance and biomass were high (24330 $\mathrm{m}^{-1}$ and $5941 \mathrm{~g} \mathrm{~m}^{-1}$ ).

The 2 Grossebucht transects included rich faunas, both having at least 20 species and abundance values in excess of $40000 \mathrm{~m}^{-1}$ (Fig. 4; Table 2). Transect VI had 20 species: 3 insects and 17 'marine' forms. Tylos granulatus, Talorchestia quadrispinosa and insects occurred in the supralittoral and a wide variety of peracarids occurred in the intertidal. Abundance was exceptionally high at $129276 \mathrm{~m}^{-1}$ and biomass was moderate at $221 \mathrm{~g} \mathrm{~m}^{-1}$ Transect VII had 21 species: 4 insects and 17 'marine' species, with peracarids being dominant. Eurydice longicornis was the only intertidal isopod. Donax serra was present on the lower shore and contributed significantly to biomass. Intertidal abundance was high at $45701 \mathrm{~m}^{-1}$ and biomass was moderate at $202 \mathrm{~g} \mathrm{~m}^{-1}$.

\section{Summary of transect ieatures}

The distinguishing features of the 7 transects are summarised in Table 2. This highlights the changes on beaches around Elizabeth Bay, with coarsest sand and poorest sorting occurring at Transect III and particle. size decreasing away from this transect. Faunal spe- 
cies richness, abundance and biomass exhibited a general decrease towards the centre of the disposal area at Transect III. One-way ANOVAs indicated significant differences in overall faunal abundance among the

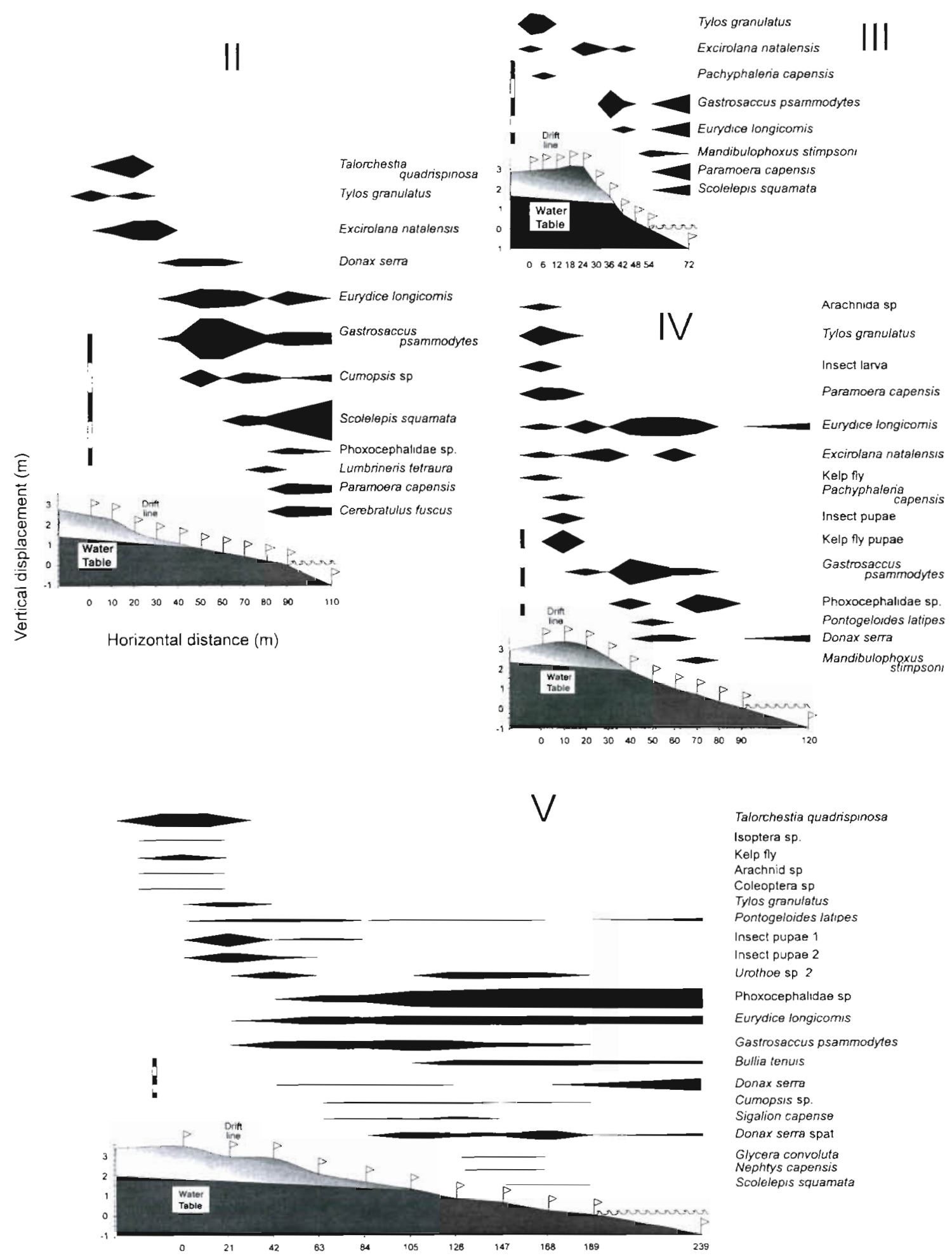

Elizabeth Bay transects $(F=40.0, p<0.001)$. Multiple range analysis, undertaken as an a posteriori test of multiple comparisons to indicate statistical significance, showed that Transects III and IV had lower

Fig. 3. Transects II-V, Elizabeth Bay. Flags indicate sampling stations with Stn 1 at the top of the shore, Stn 10 at the bottom and $-1 \mathrm{~m}$ in the sub-tidal. Kites show abundance $\mathrm{m}^{-2}$; ln scale as in Fig. 2 

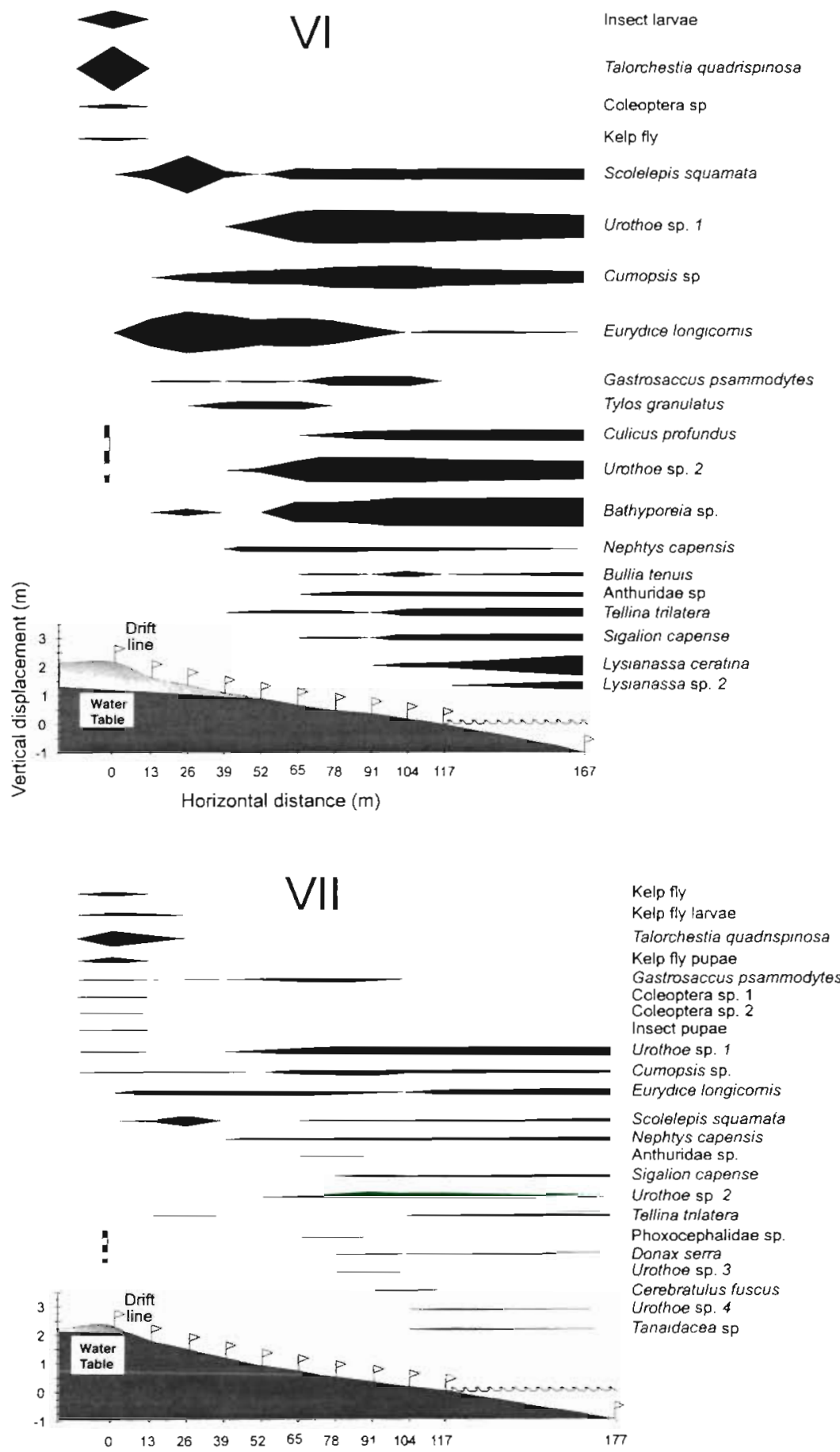

Fig. 4. Transects VI and VII, Grossebucht Bay. Flags indicate sampling stations with Stn 1 at the top of the shore, Stn 10 at the bottom and $-1 \mathrm{~m}$ in the sub-tidal. Kites show abundance $\mathrm{m}^{-2} ;$ ln scale as in Fig. 2

abundances than all other transects except Transect II. Although Transects II and III differed, Transect II did not differ from Transect IV and abundance was lower than at Transects I and V (Table 3).

Clearly, abundance is most depressed in the centre of the bay (Transect III) where tailings disposal has been greatest, and effects taper off to both sides. There were no significant differences between lines on any of the transects, but there were differences between levels (i.e. intertidal zonation) in all cases ( 1 -way ANOVA, $p<0.05$ ).

Species area curves (Fig. 5) indicate high richness at the 4 transects on dissipative beach areas (I, V, VI and VII) and lower values at the 3 intermediate sites affected by tailings (II, III and IV), with Transect III showing the most depressed species/area response.

There is a significant correlation between beach slope and number of 'marine' species (i.e. excluding insects and arachnids) on the 7 beaches (Fig. 6, $r=0.92, p<0.05)$. Slope is a useful measure of beach type and the value used is the reciprocal of overall mean slope among Strns 1 to 10 , as this is generally more sensitive than expressing the gradient in degrees. Furthermore, slope is taken for a transect as a whole and not for individual stations since the comparison is between sites (transects) subject to differing sediment conditions and not tide levels. There are also significant correlations between species richness and sand particle size and between log abundance and both slope and particle size $(p<0.05)$, confirming the interrelatedness of these determinants/indicators of beach type and the predictable response to beach type by the macrobenthic communities, i.e. a decrease in species richness and abundance as beaches become more reflective (with steeper slopes and coarser sands). In addition, a significant negative correlation was obtained between sand sorting and species richness (Spearman's Rank Correlation $=-0.83, \mathrm{p}<0.05)$, illustrating the low numbers of species in the poorly sorted sands near the outlets.

DCCA based on species and environmental attributes (Fig. 7) revealed the most distinct clustering using only 2 environmental variables: wave height and sand particle size. Clustering was less clear when slope was included. A cluster of the low to high energy dissipative sites (Transects I, V, VI and VII) is associated with decreasing particle size and the 3 intermediate sites are clearly separated towards the direction of increasing particle size. 


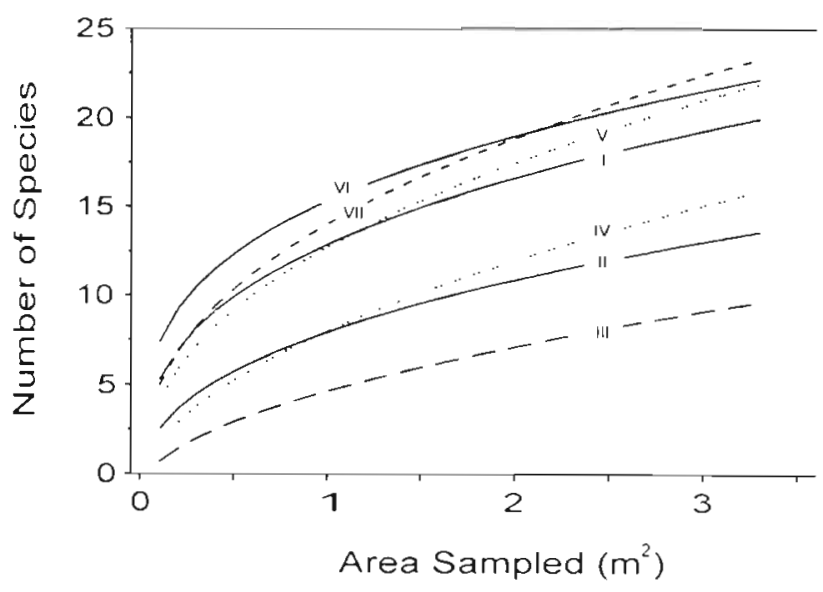

Fig. 5. Species area curves generated from 33 quadrat samples of $0.1 \mathrm{~m}^{2}$ along each of 7 transects

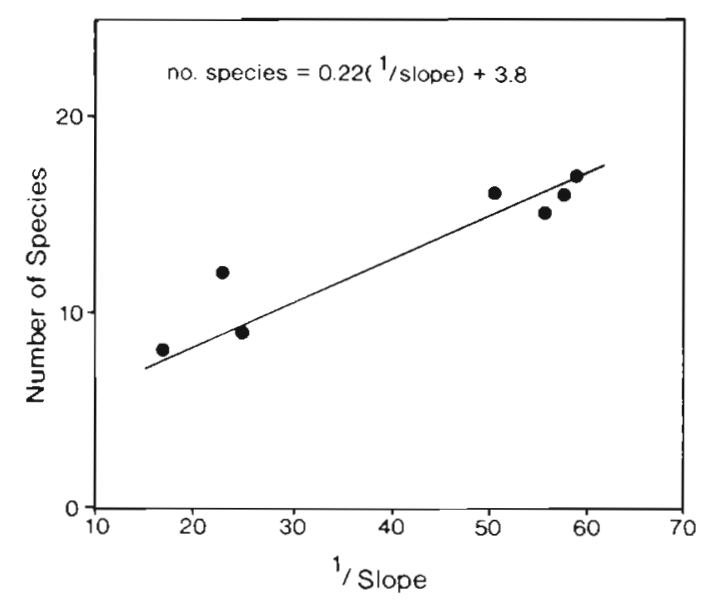

Fig. 6. Relationship between species richness and beach slope for 7 beach transects

\section{DISCUSSION}

\section{Sediment}

The sediment analysis results suggest that Elizabeth Bay beaches were originally (before 1990) composed of fine to very fine sand (mostly 100 to $150 \mu \mathrm{m}$ ), only slightly less fine than the beach at Grossebucht (mostly 90 to $95 \mu \mathrm{m}$ ). CSIR data (G. Mocke pers. comm.) indicate that original (1988) grain sizes on Elizabeth Bay beach were in the range 156 to $180 \mu \mathrm{m}$ median particle diameter, increasing slightly from west $(156 \mu \mathrm{m}$ at our Transect I) to east ( $180 \mu \mathrm{m}$ at our Transect V). Less than $10 \%$ of particles were coarser than $200 \mu \mathrm{m}$. A 1993 survey, carried out 1 yr prior to the current study, recorded mean particle diameters of $154 \mu \mathrm{m}$ and $403 \mu \mathrm{m}$ at transects $V$ and III respectively, based on intertidal samples only (McLachlan \& de Ruyck 1993). From Table 2,

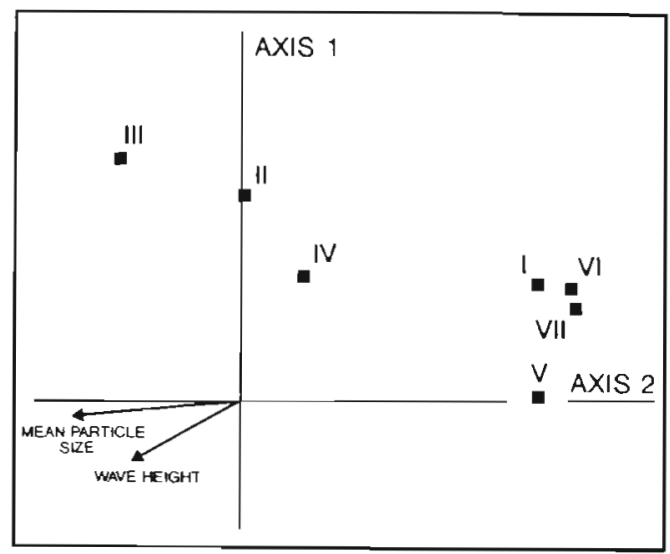

Fig. 7. DCCA plot of 7 transect lines ordinated by species and environmental data

Table 3. Results of multiple range analysis undertaken as an a posteriori test of multiple comparisons to indicate statistical significance

\begin{tabular}{|c|c|c|c|c|c|}
\hline Transect: & Ill & IV & II & I & V \\
\hline Abundance (no $\mathrm{m}^{-1}$ ) & 640 & 1067 & 4710 & 24120 & 24330 \\
\hline
\end{tabular}

it appears that sand became coarser at these 2 transect points in 1994, increasing to $199 \mu \mathrm{m}$ and $780 \mu \mathrm{m}$ respectively, suggesting recent discharge of coarser material in the case of Transect III and increasing supply of discharged material to Transect $\mathrm{V}$ by longshore drift.

It appears that sand at the exposed eastern end of Elizabeth Bay beach (Transect V, furthest from the disposal sites) increased slightly in mean particle size from about 150-180 $\mu \mathrm{m}$ before tailings disposal to around $200 \mu \mathrm{m}$ at present. In the centre of the beach (Transect III), particle size appears to have increased from about 110 to $160 \mu \mathrm{m}$ before disposal to about 600 to $900 \mu \mathrm{m}$, and in the sheltered western corner (Transect I), it increased from an original $100-150 \mu \mathrm{m}$ to 130-160 $\mathrm{mm}$. Parallelling this particle size increase was the increase in sediment load which was also greatest at Transect III; smothering is therefore also a factor to be considered.

\section{Beach state}

Grossebucht may be described as a low to medium energy dissipative beach. This state, in combination with the very fine sediment, provides an ideal habitat for beach fauna: a surf zone that thoroughly dissipates 
the incoming waves to form a mild, smooth swash action with little turbulence over the beach face. Elizabeth Bay beach is fully dissipative at its western and eastern ends and intermediate in the middle, where sand grain size has been considerably influenced by tailings disposal. All indications, based on early records of beach slope and grain size, suggest that the entire beach was dissipative before modification, ranging from low energy dissipative in the west to high energy dissipative in the east. Since beach state is determined by the interaction between wave energy and sand particle size (Short \& Wright 1983) if tide range is constant (Masselink \& Short 1993), this change is predictable. Based on the general relationship between beach state and faunal richness, such a change in beach state would also be expected to induce changes in the benthic faunal communities.

\section{Fauna}

This survey constitutes the first report on very fine sand beaches on the southwest coast of Africa. It confirms the expected richness of the fauna, with around 20 species on all the dissipative beach transects. Perhaps most exceptional is the great abundance of organisms at Grossebucht Transect VI. The 7 transects studied revealed a total of 24 species excluding insects and arachnids. Species richness was highest on the most dissipative beaches and decreased at the transects with intermediate beach types (Fig. 6), confirming the known pattern of species richness response to beach type (McLachlan et al. 1993). The fauna was dominated by peracarid crustaceans in all cases, especially amphipods, isopods and mysids, as recorded elsewhere (Dexter 1992). Only peracarids established sizeable populations on the beaches affected by tailings disposal. Molluscs were more common on transects across dissipative beaches and polychaetes were most abundant in the fine sand of Grossebucht.

The 3 intertidal isopods typical of the upper midshore in this area showed clear zonation and response to particle size changes. Excirolana natalensis occurred at the highest intertidal levels and was most successful on the transects with coarser sand. Pontogeloides latipes occurred just below it and seemed most sensitive to sand particle size, being completely absent from transects with coarse sand. Eurydice longicornis occurred on the lower shore and in the shallow surf zone over a wide range of particle sizes, but was markedly less common in the coarser sands. There thus appears to be some replacement of $P$. latipes and E. longicornis by $E$. natalensis on coarse sands in the centre of Elizabeth Bay. Similar replacement of E. longicornis by E. natalensis or other isopods in coarse sands has been recorded on the southwest coast of Africa (Brown 1973, Bally 1981). This may be related to body size, the latter being a larger species. Similar replacement of small by larger cirolanid isopods in coarse sands has been recorded on the Uruguayan coast in the case of Excirolana braziliensis replacing Excirolana armata (Defeo et al. 1992). Dugan et al. (unpubl.) have shown a tendency for the smallest species to be excluded from macrofauna communities on coarse sand beaches based on a review of numerous beach surveys.

The entire beach in Elizabeth Bay was composed of fine sand and exhibited dissipative conditions before tailings disposal. In this state, it would have harboured a species-rich fauna including elements typical of both sheltered shores and exposed beaches. Special features of such a fauna would be the diversity and abundance of peracarids, the large Donax serra populations in the subtidal and an especially high diversity for the beach as a whole - because of the presence of both sheltered shore and exposed beach communities. Many of the species found at Transect I and along both transects in Grossebucht are unlikely to be encountered intertidally anywhere on the open coasts of Namibia. Since most of the Namibian coast consists of exposed beaches of medium to coarse sand, these bay beaches with fine sand and rich faunas represent havens for many species and deserve special conservation status.

Abundance and biomass values recorded for these 7 transects cover several orders of magnitude, but all fall within the recorded range for sandy beaches (McLachlan et al. 1993). However, the exceptional abundance at Transect VI in Grossebucht is higher than any other published value for the African continent. This was due to considerable numbers of peracarids. Generally, abundance values per metre transect above 100000 are considered very high and below 1000 low for ocean beaches (McLachlan et al. in press). Only Transect III had abundance below $1000 \mathrm{~m}^{-1}$. The large sand mussel Donax serra dominated biomass wherever it occurred, as has been found elsewhere on the Namibian coast (Donn \& Cockcroft 1989). Transect V had a large biomass of sand mussels; however, sampling covered only the upper fringe of the adult population of this species and the bulk of the population, probably located between -1 and $-3 \mathrm{~m}$, still awaits accurate sampling. Both abundance and biomass values decreased dramatically from the dissipative beach states at Transects I, V, VI and VII to the transects near disposal sites.

At all transects where it occurred, Donax serra dominated biomass. An experiment on the response of this clam to a range of particle sizes (Nel. 1995) has confirmed that this species, like most bivalves (Alexander 
et al. 1993), is sensitive to particle size and has an optimum range $(200$ to $300 \mu \mathrm{m})$ in the fine to medium sand category. Since tailings disposal has raised grain sizes on affected parts of Elizabeth Bay beach into the coarse to very coarse particle size range, it is clear that Donax serra would experience great difficulty in burrowing there. The absence of this species on those beaches most affected by tailings disposal, in contrast to its presence at the other sites, lends additional support to the contention that it has been eliminated from the central portions of Elizabeth Bay by these activities. However, the disappearance of Donax serra may not be solely a result of particle size changes, and concomitant changes in beach morphology as well as smothering could also play a role. However, the mobility of the introduced sand is unlikely to be a cause of species loss per se; not only $D$. serra, but almost all species on these open beaches prefer mobile sands, many are tidal migrants, requiring dynamic environments (Brown 1983) and most are absent in sheltered sites without wave action.

\section{Conclusions}

The addition of tailings to Elizabeth Bay beach has clearly resulted in considerable accumulation of material and beach progradation. It has also increased the sand particle size of the affected sections of beach, a consequence of wave action dispersing fine fractions in the tailings and leaving coarser material behind. With wave action unchanged in the bay, the increase in particle size has converted much of the beach from dissipative to intermediate. Indeed, it appears certain that the entire beach was fully dissipative prior to 1991 , ranging from low energy dissipative in the sheltered western sector to high energy dissipative in the east. This investigation has both confirmed the suggestion (McLachlan \& de Ruyck 1993) that tailings disposal on Elizabeth Bay beach has changed beach state and faunal communities and lent support to the general hypothesis (McLachlan 1990, McLachlan et al. 1993) that changing beach state from dissipative towards more reflective conditions results in a decrease in faunal diversity and abundance.

These changes in particle size and beach morphodynamic state have had serious impacts on the fauna. Since it is well documented that dissipative beaches support richer faunas than reflective beaches (McLachlan et al. 1993), a loss in species richness and abundance of benthic macrofauna is not surprising. Particularly marked is the partial loss of a large population of the sand mussel Donax serra, which dominates the biomass in Transects I and V. The presence of this species at Grossebucht and at both ends of Eliza- beth Bay, where tailings effects are minimal, and its absence in the more affected areas in the centre of Elizabeth Bay leave little doubt that there was once a substantial population around the entire shoreline of Elizabeth Bay, probably with greatest extent and density in the east (Fig. 8).

The reasons for change in community structure, including loss of species such as sand mussels, following tailings disposal could be (1) increasing sand particle size limiting body size, burrowing rates and other functions in a variety of species; (2) smothering by rapid accumulation of tailings; (3) clogging of gills and other structures by the mud plumes associated with tailings disposal; and (4) changing beach state and concomitant changes in swash climate.

Increasing particle size can directly affect many species. It may pose lower limits to body size (Dugan et al. unpubl.) or limit burrowing performance (Alexander et al. 1993). Body size effects may account for the partial exclusion of the 2 small bodied isopod species (Eurydice longicornis and Pontogeloides latipes), whereas experimentation on Donax serra ( Nel 1995) has shown that the particle size changes recorded at Transects II-IV at Elizabeth Bay would directly decrease burrowing performance.

Smothering may also be important: at Transect III, where tailings accumulation has been greatest and the beach grew $200 \mathrm{~m}$ in 2 yrs, this amounted maximally to $27 \mathrm{~cm} \mathrm{~d}^{-1}$ or $13.5 \mathrm{~cm}$ sediment build-up per tidal cycle. At Transects II and IV, accumulation rates were considerably less, at $<5 \mathrm{~cm}$ per tidal cycle. For active beach fauna, where most species migrate with the tides and rapid burial and emergence are characteristic, even this would not necessarily cause problems. Parr et al. (1978) found less mobile species to be buried by beach replenishment activities in California (USA) but otherwise found no adverse affects; in contrast, they found opportunistic mobile crustaceans to increase in response to

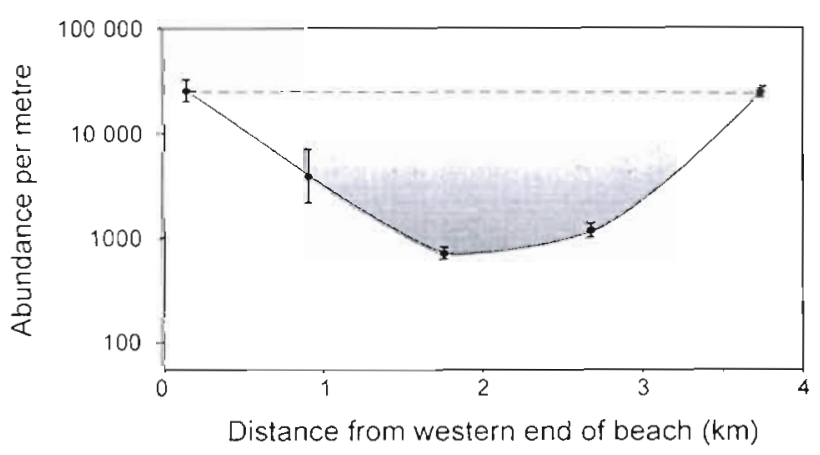

Fig. 8. Model of beach macrofaunal abundance around Elizabeth Bay before and after disposal of tailings. Broken line: original condition; solid line: 1994 condition; shaded area: loss in abundance 
replenishment, and concluded that beach communities are dynamic and adapted to seasonal (e.g. Ansell et al. 1972) and other movements of sediments and can therefore cope with both depositional and erosional conditions. Other studies of the effects of beach nourishment on benthic macrofauna have mostly found limited or negligible effects and, where there were effects, they were short-lived (Naqvi \& Pullen 1982, Gorzelany \& Nelson 1987). The Elizabeth Bay beach fauna should also be quite resilient to this type of perturbation. By contrast, removal of sand from beaches, for example by beach scraping (Wells \& McNinch 1991), may be expected to directly impact fauna through removal.

Clogging of filtering structures by turbid plumes may account for the exclusion of some species in the immediate vicinity of the discharge point. However, since vigorous wave action rapidly disperses this material into the nearshore, such effects are very unlikely at Transect IV, $1 \mathrm{~km}$ away from the discharge site. Changes in swash climate with the change in beach state from dissipative to intermediate may also play a role, but this is difficult to appraise.

The question then arises as to what remedial action should or could be taken to reduce impacts of tailings disposal, remedy the situation, or even return the beach to its original condition. Since large quantities of coarse material have now been added to the beach, are spreading laterally around the bay, and would be almost impossible to remove, it must be accepted that changes are irrevocable, at least in the medium-term. Indeed, the beach may never return to its original condition of fine sand. To prevent further deterioration of the situation, consideration could be given to disposal of further fine tailings elsewhere. These protected bays on the Namibian coast can harbour exceptionally rich faunas. Since Elizabeth Bay has already been detrimentally affected by tailings disposal, but Grossebucht is in pristine condition, the latter should enjoy particularly high conservation status. Until such time as surveys reveal other bays with faunas to match Grossebucht, its beach should be carefully shielded from any major disturbances such as those which have occurred in Elizabeth Bay.

This study has supported the contention that changing a microtidal beach from a dissipative to a more reflective state would result in a reduction in faunal species richness and abundance (McLachlan et al. 1993). In this case, the changes have been due to changes in particle size, and wave action has remained unchanged. It would be of great fundamental interest to beach ecology to compare this scenario to one in which particle size was kept constant and wave energy levels changed. Such an experiment would provicte a unique opportunity to contrast the influences of the 2 key elements of beaches particle size and swash climate - on the fauna.
Acknowledgements. I thank CDM for funding this study through Mr Mike Lain, Ore Reserves Manager. I also thank Ms Joanne Daneel for much patient and willing assistance and good company, Dave Schoeman, Ronel Vel, Rebecca Sims, Andy Bentley and Mike Farquhar for cheerful assistance with field and laboratory work and data analysis, Ms Dawn Flegg for sediment analyses and Dr Gary Mocke (CSIR) for informatıon on sand particle sizes prior to tailıngs disposal. The Oranjemund Dive Club and Namibian Sed Fisheries at Luderitz kindly provided and filled aqualungs.

\section{LITERATURE CITED}

Alexander RR, Stanton RJ, Dodd JR (1993) Influence of sediment grain size on the burrowing of bivalves. Palaios 8: $289-303$

Ansell AD, Sivadas P, Narayanan B, Sankkaranarayanan VN, Trevallion A (1972) The ecology of two sandy beaches in southwest India: 1. Seasonal changes in physical and chemical factors, and in the macrofauna. Mar Biol 17: $38-62$

Bally R (1981) The ecology of three sandy beaches on the west coast of South Africa. PhD thesis. University of Cape Town

Brown AC (1973) The ecology of sandy beaches of the Cape Peninsula, South Africa. Part 4. Observations on two intertidal Isopoda: Eurydice longicornis (Studer) and Exosphaeroma truncatitelson Barnard Trans R Soc S Afr 40: $381-404$

Brown AC (1983) The ecophysiology of sandy beach animals - a partial review. In: McLachlan A, Erasmus $T$ (eds) Sandy beaches as ecosystems. Junk, The Hague, p $575-605$

CSIR (1993a) Elizabeth Bay monitoring project 1992 review. CSIR Contract Report

CSIR (1993b) The composition and dynamics of turbid seawater at Elizabeth Bay. CSIR Contract Report

Defeo O, Jaramillo E, Lyonnet A (1992) Community structure and intertidal zonation of the macroinfauna on the Atlantic coast of Uruguay. J coastal Res 8:830-839

Dexter DM (1992) Sandy beach community structure: the role of exposure and latitude. J Biogeogr 19:59-66

Donn. TE, Cockcroft AC (1989) Macrofauna community structure and zonation of two sandy beaches on the central Namib coast, South West Africa/Namibia. Madoqua 16:129-135

Gorzelany JF, Nelson WG (1987) The effects of beach replenishment on the benthos of a sub-tropical Florida beach. Mar Environ Res 21:75-94

Gray JS (1974) Animal-sediment relationships. Oceanogr mar Biol A Rev 12:223-261

Hartnoll R (1983) The species-area relationship on a sandy beach. In: McLachlan A. Erasmus T (eds) Sandy beaches as ecosystems. Junk, The Hague, p 473-479

Jaramillo E, McLachlan A, Coetzee P (1993) Intertidal zonation patterns of macroinfauna over a range of exposed sandy beaches in south-central Chile. Mar Ecol Prog Ser 101:105-118

Johnson RG (1971.) Animal-sediment relations in shallow water benthic communities. Mar Geol 11:93-104

Masselink G, Short AD (1994) Morphodynamics of macrotidal beaches. J coastal Res 9:785-800

McArdle S, McLachlan A (1992) Sand beach ecology: swash features relevant to the macrofauna. J coastal Res 8: $398-407$

McLachlan A (1990) Dissipative beaches and macrofauna communities on exposed intertidal sands, J coastal Res 6 . $57-71$ 
McLachlan A, de Ruyck AMC (1993) Survey of sandy beaches in Diamond Area 1. Contract Report to CDM, Oranjemund, Namibia

McLachlan A, de Ruyck AMC, Hacking N (in press) Community structure on sandy beaches: patterns of richness and zonation in relation to tide range and latitude. Rev Biol Chlena

McLachlan A, Jaramillo E, Donn TE, Wessels F (1993) Sandy beach macrofauna communities and their control by the physical environment: a geographical comparison. $J$ coastal Res Spec Issue 15:27-38

Naqvi SM, Pullen EJ (1982) Effects of beach nourishment and borrowing on marine organisms. US Army Corps Engineers, Misc Rep 82-14:1-43

Nel P (1995) The effects of sand particle size on beach fauna. $\mathrm{MSc}$ thesis, University of Port Elizabeth

Olafsson EB, Peterson CH, Ambrose WG (1994) Does recruitment limitation structure populations and communities

This article was submitted to the editor of macro-invertebrates in marine soft sediments: the relative significance of pre- and post-settlement processes. Oceanogr mar Biol A Rev 32:65-109

Parr T, Diener D, Lacy S (1978) Effects of beach replenishment on the nearshore sand fauna at imperial Beach, Ca!ifornia. US Army Corps of Engineers, Misc Rep 78-4:1-15

Short AD. Wright LD (1983) Physical variabllity of sandy beaches. In: Mclachlan A, Erasmus $T$ (eds) Sandy beaches as ecosystems. Junk, The Hague, p 133-144

Ter Braak CJF (1987) CANOCO-FORTRAN program for canonucal community ordination by (partial) (detrended) (canonical) correspondence analysis and redundancy analysis (Version 2.1). TNO Institute of Applied Computer Science, Statustical Department, Wageningen, Netherlands

Wells JT, McNinch J (1991) Beach scraping in North Carolina with special reference to its effectiveness during Hurricane Hugo. J coastal Res Spec Issue 8:249-261

Manuscript first received: November 20, 1994

Revised version accepted: July 31, 1995 